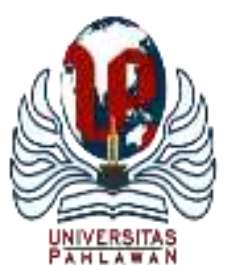

Edukatif : Jurnal Ilmu Pendidikan Volume 3 Nomor 6 Tahun 2021 Halm 4041 - 4048

EDUKATIF: JURNAL ILMU PENDIDIKAN

Research \& Learning in Education

https:/ledukatif.org/index.php/edukatif/index

\title{
Implementasi Model Pembelajaran Kooperatif Make A Match (MAM) dalam Peningkatan Hasil Belajar pada Materi Sistem Ekskresi
}

\author{
Masni Veronika Situmorang ${ }^{1 凶}$, Natalina Purba $^{2}$, Binsar Tison Gultom ${ }^{3}$ \\ Universitas HKBP Nommensen Pematangsiantar,Indonesia ${ }^{1,2,3}$ \\ E-mail : masniveronika@gmail.com ${ }^{1}, \underline{\text { natalinapurba@aol.com }}^{2}, \underline{\text { binsartisongultom @ gmail.com }}^{3}$
}

\begin{abstract}
Abstrak
Penelitian ini bertujuan untuk mengetahui hasil belajar siswa melalui penerapan model pembelajaran kooperatif Make A Match (MAM) pada materi sistem ekskresi. Penelitian ini adalah jenis penelitian deskriptif. Populasi dalam penelitian ini adalah seluruh siswa kelas XI IPA SMA Negeri 1 Pematangsiantar yang terdiri dari 3 kelas. Pengambilan sampel secara purposive sample, yaitu kelas XI IPA 2 sebanyak 30 orang siswa. Instrumen yang digunakan untuk mengumpulkan data berupa tes tertulis berbentuk pilihan berganda. Sebelum soal diberikan kepada siswa, terlebih dahulu dilakukan uji validitas, uji reliabilitas, daya pembeda soal, dan tingkat kesukaran soal. Hasil analisis data diperoleh nilai rata-rata siswa setelah mendapat pengajaran dengan penerapan model pembelajaran kooperatif Make A Match (MAM) mengalami peningkatan nilai sebesar $47,01 \%$, penguasaan siswa sebesar $77,44 \%$, ketuntasan secara individu maupun klasikal sebesar $90 \%$. Berdasarkan hasil penelitian yang diutarakan di atas, dapat disimpulkan bahwa pembelajaran dengan penerapan model pembelajaran kooperatif Make A Match (MAM) pada materi sistem ekskresi dapat diterapkan dengan baik.
\end{abstract}

Keywords: Pembelajaran Kooperatif Make A Match (MAM), Hasil Belajar

\section{Abstract}

This study aims to determine student learning outcomes through the application of the Make A Match (MAM) cooperative learning model to the excretory system material. This research is a type of descriptive research. The population in this study was all students of class XI IPA SMA Negeri 1 Pematangsiantar which consisted of 3 classes. Sampling by purposive sample, namely class XI IPA2 as many as 30 students. The instrument used to collect data is a written test in the form of multiple choice. Before the questions are given to students, validity tests, reliability tests, discriminatory questions, and the level of difficulty of the questions are first tested. The results of data analysis showed that the average value of students after receiving teaching with the application of the Make A Match (MAM) cooperative learning model increased in value by $47.01 \%$, student mastery by 77.44\%, individual and classical completeness by $90 \%$. Based on the results of the research described above, it can be concluded that learning by applying the Make A Match (MAM) cooperative learning model to the excretory system material can be applied well.

Keywords: Make A Match (MAM) Cooperative Learning, Learning Outcomes

Copyright (c) 2021 Masni Veronika Situmorang, Natalina Purba, Binsar Tison Gultom $\triangle$ Corresponding author:

Email : masniveronika@gmail.com

DOI $\quad$ : https://doi.org/10.31004/edukatif.v3i6.1286

ISSN 2656-8063 (Media Cetak)

ISSN 2656-8071 (Media Online)

Edukatif : Jurnal Ilmu Pendidikan Vol 3 No 6 Tahun 2021 p-ISSN 2656-8063 e-ISSN 2656-8071 
4042 Implementasi Model Pembelajaran Kooperatif Make A Match (MAM) dalam Peningkatan Hasil Belajar pada Materi Sistem Ekskresi - Masni Veronika Situmorang, Natalina Purba, Binsar Tison Gultom

DOI: https://doi.org/10.31004/edukatif.v3i6.1286

\section{PENDAHULUAN}

Undang-Undang Sistem Pendidikan Nasional No. 20 tahun 2003 Bab I Pasal 1 menyatakan bahwa: "Pendidikan adalah usaha sadar dan terencana untuk mewujudkan suasana belajar dan proses pembelajaran agar peserta didik secara aktif mengembangkan potensi dirinya untuk memiliki kekuatan spiritual keagamaan, pengendalian diri, kepribadian, kecerdasan, akhlak mulia, serta keterampilan yang diperlukan dirinya, masyarakat, bangsa dan negara". Guru merupakan ujung tombak keberhasilan kegiatan pembelajaran di sekolah yang terlibat langsung dalam merencanakan dan melaksanakan kegiatan pembelajan. Kualitas kegiatan pembelajaran yang dilakukan sangat bergantung pada perencanaan dan pelaksanaan proses pembelajaran yang dilakukan guru. Tugas guru bukan semata-mata mengajar (teacher centered), tetapi lebih kepada membelajarkan siswa (student centered) (Haruna \& Darwis, 2020).

Dari hasil wawancara yang dilakukan peneliti dengan salah satu guru bidang studi Biologi terdapat beberapa permasalahan yang ditemukan pada kelas XI IPA di MAN 1 Medan tahun pelajaran 2015/2016 seperti kelas masih berfokus pada guru, proses pembelajaran masih banyak yang tidak melibatkan siswa sehingga siswa menjadi pasif. Guru masih menggunakan model pembelajaran yang lebih memfokuskan pada pengumpulan pengetahuan dan penuntasan materi menggunakan metode ceramah dan penugasan dimana guru sebagai pusat informasi menerangkan materi dan siswa hanya duduk manis mendengarkan dan mencatat materi yang disampaikan. Permasalahan dari materi sistem ekskresi yang dialami siswa adalah dimana siswa masih belum atau kurang mengenal dan memahami organ-organ yang termasuk kedalamsistem ekskresi, kurang mampunya siswa menjelaskan bagaimana proses-proses yang terjadi pada sistem ekskresi, dan kurang mampunya siswa mengingat serta menggunakan bahasa latin pada materi sistem ekskresi. Permasalahan lainnya adalah tingginya nilai KKM dari pelajaran Biologi sehingga hasil belajar siswa belum maksimal karena hanya sebagian siswa yang nilainya mencapai KKM (Eka Rizki Ananda Nasution, 2016).

Adapun faktor-faktor yang mempengaruhi hasil belajar secara garis besar ada dua, yaitu: Faktor internal faktor eksternal. Diantara berbagai faktor tersebut, faktor guru dan minat belajar siswa yang diduga berpengaruh terhadap keberhasilan proses pembelajaran(Slameto, 2010).

Hasil yang diperoleh lainnya siswa juga tidak suka pembelajaran biologi yang diajarkan dengan ceramah, hal ini diperoleh dari observasi terhadap siswa yang berada di sekolah tersebut. Penggunaan metode ceramah akan membuat peserta didik jenuh dan bosan, sehingga peserta didik kurang berminat dalam mempelajari pelajaran yang diberikan (Link et al., 2019). Oleh karena itu guru yang bersangkutan pernah mencoba membuat diskusi kelompok, namun pada saat diskusi berlangsung, masih banyak siswa yang hanya bermain-main saat diskusi, tidak paham dengan materi yang sedang didiskusikan, dan siswa yang pintar lebih mendominasi jalannya diskusi.

Keberhasilan belajar sangat bergantung kepada sejumlah variabel yang saling berinteraksi dalam bentuk faktor eksternal dan internal. Menurut (Winansih, 2009) bahwa faktor yang mempengaruhi prestasi belajar dapat berupa: (1) faktor internal (faktor dari dalam diri siswa), yakni keadaan/ kondisi jasmani dan rohani siswa, (2) faktor eksternal (faktor dari luar siswa) yakni kondisi lingkungan disekitar rumah siswa. (3) faktor pendekatan belajar (approach to learning) yakni jenis upaya belajar siswa yang meliputi strategi dan metode yang digunakan siswa untuk melakukan kegiatan pembelajaran materi- materi pelajaran

Keberhasilan berdasarkan pendekatan belajar (Approach to lerning) Sekarang ini sangat dibutuhkan karena pembelajaran di tumpukan berdasarkan competence based dimana pembelajaran lebih di fokuskan siswa mencari sendiri guru hanya sebagai fasilitator untuk keberhasilan belajar tersebut. Hasil belajar siswa sangat dipengaruhi oleh kegiatan proses belajar mengajar yang di dalamnya terdapat beberapa faktor yang merupakan penentu lancar atau tidaknya kegiatan proses belajar mengajar. 
4043 Implementasi Model Pembelajaran Kooperatif Make A Match (MAM) dalam Peningkatan Hasil Belajar pada Materi Sistem Ekskresi - Masni Veronika Situmorang, Natalina Purba, Binsar Tison Gultom

DOI: https://doi.org/10.31004/edukatif.v3i6.1286

Dalam (Michael, 2003) menggambarkan "Cooperative learning” sebagai suatu metode instruksional yang mana para siswa bekerja sama di dalam regu kecil untuk belajar suatu materi bahasan yang diberikan oleh guru. Para siswa mengambil tanggung jawab untuk materi mereka sendiri dalam kelompok. Mereka belajar manajemen kelas dengan mengecek dan monitoring, membantu satu sama lain dengan permasalahan dan memberi harapan kepada yang memberikan harapan satu sama lain untuk mencapai suatu hasil.

Namun, keberhasilan penerapan cooperative learning sangat tergantung pada ketepatan memilah model (Lie, 2008) menyebutkan beberapa model yang dapat digunakan dalam pengajaran, termasuk pengajaran sejarah sebagai berikut: Make A Match atau mencari pasangan, bertukar pasangan, berpikir berpasangan berempat, kepala bernomor, dua tinggal dua tamu, teknik dua tinggal dua tamu, jigsaw, kancing gemerincing, dan lingkaran besar lingkaran kecil.

Pembelajaran biologi merupakan cara mencari tahu tentang alam secara sistematis (Sayuti et al., 2016). Materi sistem ekskresi materi pokok yang banyak dengan istilah dan gambar- gambar yaitu paru-paru, hati, kulit dan ginjal. Oleh karena itu, pelajaran tersebut sebaiknya disampaikan dengan sistem diskusi atau membuat kelompok diskusi dimana siswa turut berperan aktif untuk bertanya dan dapat melibatkan seluruh siswa di kelas. Oleh sebab itu dari berbagai model pembelajaran kooperatif, Model Make A Match merupakan model yang tepat untuk sistem ekskresi. Model Make A Match adalah bentuk pengajaran dengan cara mencari pasangan kartu yang telah dimiliki dan pasangan bisa dalam bentuk orang per orang apabila jumlah siswa banyak, kemudian berhadapan untuk saling menjelaskan makna kartu yang dimiliki (Herdian, 2009).

Berdasarkan (H \& Halimah, 2017) bahwa hasil belajar siswa yang mendapatkan pembelajaran dengan menggunakan model pembelajaran kooperatif tipe make a match lebih baik dibandingkan dengan menggunakan pendekatan pembelajaran konvensional. Dan menurut (Takdir, 2018) ada pengaruh positif model pembelajaran Kooperati Tipe Make A Match terhadap hasil belajar peserta didik SMP Negeri 4 Kahu Studi Pada Materi Pokok Ekosistem. Menurut (Eliza Nola Dwi Putri1, 2020) menujukkan bahwa model kooperatif tipe Make A Match berpengaruh terhadap hasil belajar IPS siswa kelas V dengan skor t-hitung $(4,9045)>$ t-tabel $(1,697)$. Menurut (Syofiana et al., 2018) bahwa secara umum hasil belajar maupun motivasi belajar siswa dengan penerapan model pembelajaran kooperatif tipe TGT lebih tinggi dibandingkan model pembelajaran kooperatif tipe MM.Hal ini ditunjukan dengan t hitung $>\mathrm{t}$ tabel,dimana 1,7515 > 1,6662 untuk hasil belajar dan 8,9804>1,6662 untuk motivasi belajar siswa. Dengan kata lain terdapat perbedaan yang signifikan dari hasil belajar maupun motivasi belajar siswa dengan penerapan model pembelajaran kooperatif tipe Make A Match (MM) dan model pembelajaran kooperatif tipe Team Games Tournament (TGT). Adapun tujuan penelitian ini dilakukan adalah untuk mengetahui hasil belajar siswa melalui penerapan model pembelajaran kooperatif Make A Match (MAM) pada materi sistem ekskresi.

\section{METODE PENELITIAN}

Penelitian ini termasuk penelitian deskriptif (Sudjana, 2010). Cara pengambilan sampel dalam penelitian ini adalah dengan cara purporsive sampel yaitu kelas XI IPA 2 berjumlah 30 orang. Teknik pengumpulan data pada penelitian ini berupa tes hasil belajar. Penerapan suatu metode pada penelitian ini ditinjau dari aspek tingkat penguasaan materi pembelajaran pada siswa, ketuntasan belajar secara individual, ketuntasan belajar secara klasikal.

\section{HASIL DAN PEMBAHASAN PENELITIAN}

Berdasarkan hasil jawaban siswa maka diperoleh skor setiap siswa dalam pembelajaran sistem ekskresi. Dari skor tersebut diukur tingkat pemahaman siswa dalam menyelesaikan soal-soal yang berkaitan dengan sistem ekskresi. Tingkat penguasaan siswa merupakan tinggi rendahnya nilai yang diperoleh siswa bedasarkan hasil jawaban tes yang diberikan. Untuk mengetahui tingkat penguasaan siswa mengenai materi pokok sistem 
4044 Implementasi Model Pembelajaran Kooperatif Make A Match (MAM) dalam Peningkatan Hasil Belajar pada Materi Sistem Ekskresi - Masni Veronika Situmorang, Natalina Purba, Binsar Tison Gultom

DOI: https://doi.org/10.31004/edukatif.v3i6.1286

ekskresi digunakan rumus Presentase Penguasaan Siswa (PPS) yang diadopsi dari rumus Suryosubroto (2007). Adapun ringkasan persentase tingkat penguasaan siswa tersaji pada tabel di bawah ini:

Tabel 1

Persentase Tingkat Penguasaan Siswa pada saat Pre test

\begin{tabular}{|c|c|c|c|}
\hline $\begin{array}{l}\text { Persentase } \\
\text { Penguasaan }\end{array}$ & $\begin{array}{l}\text { Tingkat } \\
\text { Penguasaan }\end{array}$ & $\begin{array}{l}\text { Banyak } \\
\text { Siswa }\end{array}$ & $\begin{array}{l}\text { Persentase } \\
\text { Jumlah Siswa }\end{array}$ \\
\hline $90 \%-100 \%$ & Sangat Tinggi & 0 & $0 \%$ \\
\hline $80 \%-89 \%$ & Tinggi & 0 & $0 \%$ \\
\hline $65 \%-79 \%$ & Sedang & 0 & $0 \%$ \\
\hline $55 \%-64 \%$ & Rendah & 0 & $0 \%$ \\
\hline $0-\quad 54 \%$ & Rendah Sekali & 30 & $100 \%$ \\
\hline Total & & 30 & $100 \%$ \\
\hline
\end{tabular}

Tabel 2

Persentase Tingkat Penguasaan Siswa pada saat Post test

\begin{tabular}{llll}
\hline $\begin{array}{l}\text { Persentase } \\
\text { Penguasaan }\end{array}$ & $\begin{array}{l}\text { Tingkat } \\
\text { Penguasaan }\end{array}$ & Banyak Siswa & $\begin{array}{l}\text { Persentase } \\
\text { Jumlah Siswa }\end{array}$ \\
\hline $90 \%-100 \%$ & Sangat Tinggi & 6 & $20 \%$ \\
\hline $80 \%-89 \%$ & Tinggi & 8 & $26,7 \%$ \\
\hline $65 \%-79 \%$ & Sedang & 13 & $43,3 \%$ \\
\hline $55 \%-64 \%$ & Rendah & 3 & $10 \%$ \\
\hline $0 \%-54 \%$ & Sangat Rendah & 0 & 0 \\
\hline Total & & 30 & $100 \%$ \\
\hline
\end{tabular}

Berdasarkan perhitungan pada tabel 1 untuk persentase tingkat penguasaan siswa pada saat pre test di atas dari 30 orang siswa diantaranya diperoleh 30 orang siswa yang tingkat penguasaannya sangat rendah (100\%). Sedangkan pada tabel 2 persentase tingkat penguasaan siswa pada saat post test dari 30 orang siswa yang tingkat penguasaannya sangat tinggi (20\%), 8 orang siswa yang tingkat penguasaannya tinggi (26,7\%), dan 13 orang siswa yang memiliki tingkat pengusaan sedang $(43,33 \%)$ dan terdapat 3 siswa yang masuk kedalam kategori tingkat pengusaan sangat rendah (10\%). Sehingga dilihat bahwa skor rata-rata tingkat penguasaan siswa saat post test sebesar 77,44. Dan untuk lebih jelasnya dapat dilihat pada diagram batang di bawah ini.

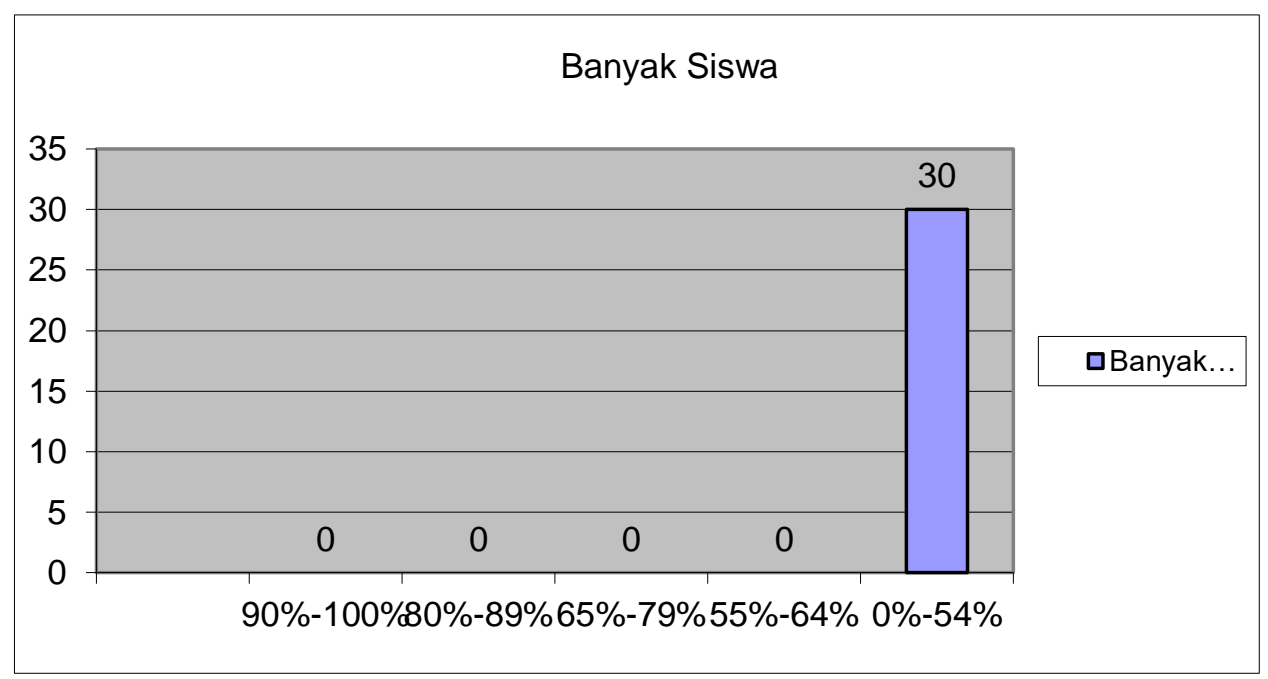

Gambar 1. Diagram Batang Tingkat Penguasaan Siswa pada Pre Test 
4045 Implementasi Model Pembelajaran Kooperatif Make A Match (MAM) dalam Peningkatan Hasil Belajar pada Materi Sistem Ekskresi - Masni Veronika Situmorang, Natalina Purba, Binsar Tison Gultom

DOI: https://doi.org/10.31004/edukatif.v3i6.1286

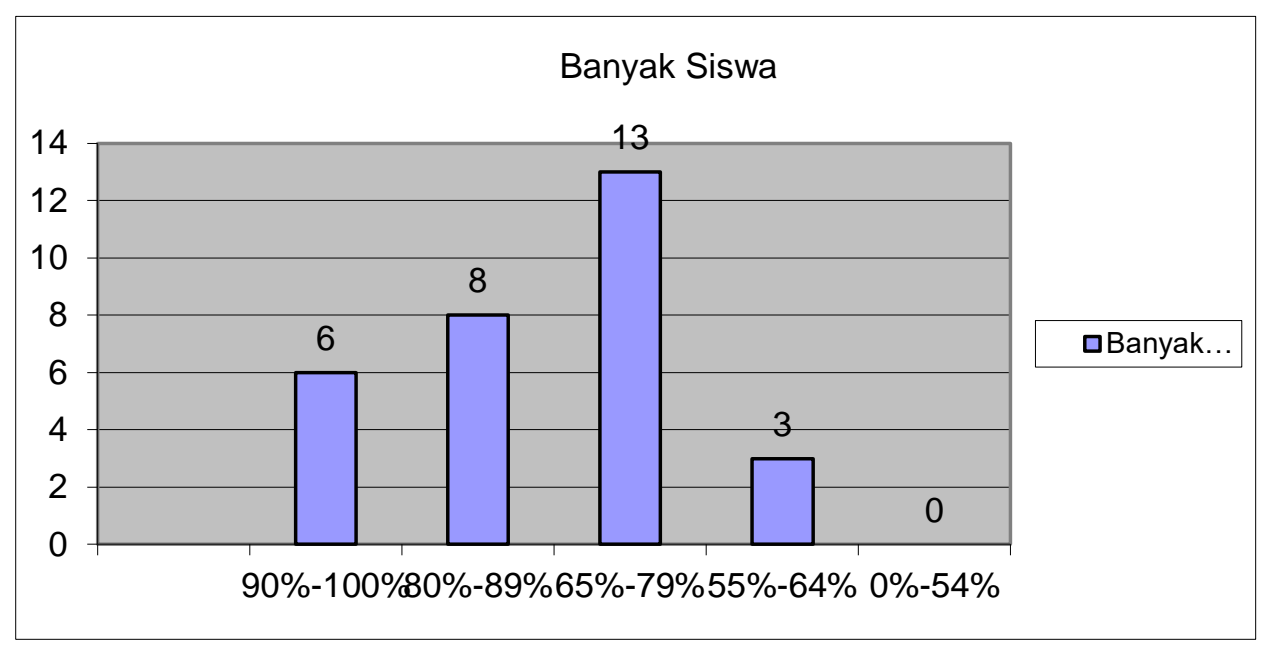

Gambar 2. Diagram Batang Tingkat Penguasaan Siswa pada Post Test

Dapat dilihat dari diagram batang berdasarkan data penguasaan siswa dari hasil pre test ke post test perbedaannya dapat dilihat dengan jelas.

Untuk menentukan keefektifan dan pencapaian yang diharapkan dalam pembelajaran sistem ekskresi, dapat dilihat juga dari ketuntasan belajar siswa yang didasarkan pada kriteria ketuntasan belajar secara perorangan dan klasikal. Ketuntasan belajar siswa dalam pembelajaran sistem ekskresi adalah 27 dari 30 orang siswa atau $90 \%$ telah tuntas belajar dan 3 orang siswa atau $10 \%$ tidak tuntas belajar. Persentase tingkat ketuntasan belajar siswa dalam pembelajaran sistem pernapasan manusia disajikan pada tabel berikut :

Tabel 3

Persentase Tingkat Ketuntasan Belajar Siswa

\begin{tabular}{llllll}
\hline No. & $\begin{array}{l}\text { Persentase } \\
\text { Ketuntasan }\end{array}$ & $\begin{array}{l}\text { Tingkat } \\
\text { Ketuntasan }\end{array}$ & $\begin{array}{l}\text { Banyak } \\
\text { Siswa }\end{array}$ & $\begin{array}{l}\text { Peersentase } \\
\text { Siswa }\end{array}$ & Jumlah \\
\hline 1. & $<$ nilai 65 & Tidak tuntas & 3 & $10 \%$ & \\
\hline 2. & $\geq$ nilai 65 & Tuntas & 27 & $90 \%$ & \\
\hline
\end{tabular}

Berdasarkan data tingkat ketuntasan belajar siswa dalam pembelajaran sistem ekskresi terdapat 27 orang siswa dari 30 orang siswa telah tuntas belajar sementara 3 orang siswa lainnya belum tuntas belajar. Dengan demikian ketuntasan belajar secara klasikal (kelompok) pada kelas XI IPA ${ }^{2}$ SMA Negeri 1 Pematangsiantar T.P 2009/ 2010 telah terpenuhi karena terdapat $90 \%$ dari 30 orang siswa telah mencapai skor diatas 65 atau minimum 65.

Pada proses pembelajaran, observer mengamati aktivitas siswa di kelas dengan menggunakan model pembelajaran kooperatif Make A Match (MAM). Observer melakukan observasi dengan melihat aktivitas siswa ketika sedang melaksanakan Kegiatan Belajar Mengajar (KBM). Kriteria yang digunakan untuk mengukur aktivitas mereka berdasarkan sintaks (langkah- langkah) dalam pembelajaran kooperatif Make A Match (MAM). Dari hasil observasi yang telah dilaksanakan di kelas XI IPA ${ }_{2}$, dapat diambil kesimpulan bahwa siswa memiliki aktivitas yang baik saat kegiatan pembelajaran dengan model kooperatif tipe Make A Match..

Dengan membandingkan nilai test yang diperoleh pada waktu pre test dan post test, kita akan dapat mengetahui apakah tujuan mengajar kita tercapai atau tidak. Tegasnya apakah proses interaksi edukatif tersebut berhasil atau tidak. Dikatakan tercapainya tujuannya bila nilai post test secara keseluruhan lebih tinggi dari nilai pre test. Sebaliknya bila nilai post test lebih rendah dari nilai pre test, artinya tujuan yang diharapkan belum tercapai. 
4046 Implementasi Model Pembelajaran Kooperatif Make A Match (MAM) dalam Peningkatan Hasil Belajar pada Materi Sistem Ekskresi - Masni Veronika Situmorang, Natalina Purba, Binsar Tison Gultom

DOI: https://doi.org/10.31004/edukatif.v3i6.1286

Berdasarkan analisis, diperoleh petunjuk bahwa model pembelajaran kooperatif tipe Make A Match (MAM) dapat diterapkan untuk pembelajaran biologi khususnya dalam materi pokok sistem eksresi. Penerapan pembelajaran dapat dilihat dari uraian beberapa kriteria berikut:

\section{Tingkat Penguasaan Siswa}

Dari hasil jawaban siswa, maka diperoleh skor setiap siswa dalam kegiatan belajar mengajar pada materi pokok Sistem ekskresi dimana dari skor yang diperoleh dapat diukur tingkat kemampuan siswa dalam menyelesaikan soal-soal yang berkaitan dengan sistem ekskresi tersebut.

Berdasarkan hasil analisis deskriptif terhadap skor yang diperoleh siswa terlihat bahwa:

a. Pre test

Tingkat penguasaan siswa pada saat pre test tampak jelas terdapat pada kategori rendah sekali berkisar (0-54\%) yaitu rata- rata 30,43\%. Pre test merupakan suatu alat yang digunakan untuk membandingkan nilai test yang diperoleh pada waktu pre test dan post test, kita akan dapat mengetahui apakah tujuan mengajar kita tercapai atau tidak.

b. Post test

Setelah dilaksanakan post test tingkat penguasaan siswa sebesar $77,44 \%$ telah mencapai tingkat penguasaan yang diharapkan karena tingkat penguasaan siswa secara klasikal (kelas) berada pada kategori sedang (65-79). Dari data yang diperoleh terdapat 6 orang yang memiliki tingkat penguasaan sangat tinggi atau $20 \%$, terdapat 8 orang yang memiliki tingkat penguasaan tinggi atau 26,7\%, terdapat 13 orang yang memiliki tingkat penguasaan sedang atau $43,3 \%$, dan terdapat 3 orang yang memiliki tingkat penguasaan rendah atau $10 \%$. Dengan demikian, dari 30 orang siswa di kelas XI IPA $\mathrm{IP}_{2}$ diperoleh 3 orang siswa yang belum berhasil dalam penguasaan materi pokok sistem ekskresi. Sedangkan 27 siswa lainnya berhasil menguasai materi pokok tersebut.

Berdasarkan penelitian sebelumnya, dapat dilihat bahwa model Make A Match (MAM) berkontribusi untuk penyebaran penguasaan siswa untuk kategori sangat tinggi (Eliya, 2009). Sedangkan penelitian ini pada materi sistem ekskresi, rata- rata pre test 30,43 , dan post test 77,4 maka peningkatan belajar yaitu sebesar 47,01\%. Hal ini sesuai dengan penelitian (Ferdiana, 2020) pemberian model pembelajaran kooperatif tipe make a match berpengaruh terhadap pemahaman konsep matematika dan meningkatkan hasil belajar siswa.

\section{Ketuntasan Belajar Siswa}

Untuk mengetahui keefektifan proses belajar mengajar yang dilakukan oleh guru dan pencapaian yang diharapkan dapat dilihat dengan ketuntasan belajar siswa. Dengan cara seperti ini guru dapat mengetahui berhasil atau tidak dalam mengajar. 
4047 Implementasi Model Pembelajaran Kooperatif Make A Match (MAM) dalam Peningkatan Hasil Belajar pada Materi Sistem Ekskresi - Masni Veronika Situmorang, Natalina Purba, Binsar Tison Gultom

DOI: https://doi.org/10.31004/edukatif.v3i6.1286

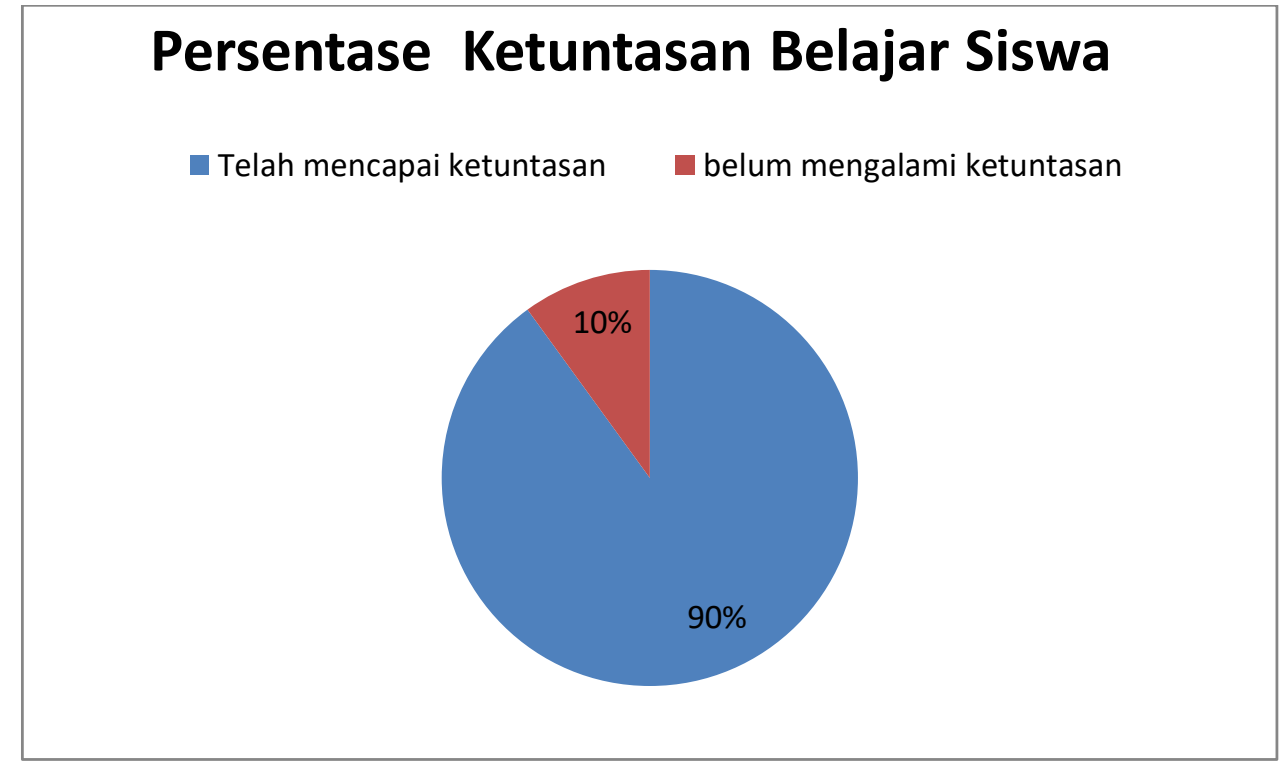

\section{Gambar 3. Hasil Ketuntasan Belajar Siswa}

Model pembelajaran kooperatif Make A Match (MAM) mampu meningkatkan aktivitas siswa untuk lebih berperan menggali ilmu pengetahuan mengenai materi pokok sistem ekskresi. Siswa tidak hanya mendapatkan informasi dari guru saja, tetapi dari teman lainnya. Pengajaran ini dapat juga dikatakan dengan pengajaran teman sebaya. Selama proses pembelajaran berlangsung, siswa saling bekerja sama untuk menuntaskan tujuan pembelajaran. Siswa yang pandai akan membantu siswa yang kurang pandai demi prestasi kelompok sebagai satu kesatuan. Setiap siswa tidak hanya bertanggung jawab atas kemajuan dan keberhasilan dirinya, tetapi bertanggung jawab atas keberhasilan dan kemajuan kelompoknya.

Dalam penerapannya banyak hal yang mempengaruhi siswa agar lebih aktif dalam kegiatan pembelajaran dengan metode diskusi, dalam pembelajaran ini guru sebagai fasilitator. Akan tetapi disebabkan keterbatasan waktu dan belum terbiasanya siswa dalam melakukan diskusi Make A Match ini, maka hal-hal yang diharapkan belum tercapai secara maksimal, dan terdapat juga hal-hal yang tidak diinginkan dalam pembelajaran.

Dari keterangan pembahasan di atas, dengan melihat data hasil belajar siswa dapat memenuhi tingkat penguasaan secara individual dan klasikal 90\%, siswa memiliki penguasaan $65 \%$ atau nilai 65 keatas, $90 \%$ memenuhi tingkat ketuntasan belajar secara klasikal. Maka, hasil belajar siswa dengan model pembelajaran Kooperatif Make A Match (MAM) pada materi pokok sistem ekskresi di kelas XI-IPA 2 adalah baik.

\section{KESIMPULAN}

Berdasarkan hasil pembahasan dapat dilihat bahwa hasil belajar dan ketuntasan belajar siswa melalui penerapan model pembelajaran kooperatif Make A Match (MAM) pada materi sistem ekskresi meningkat dengan baik.

\section{UCAPAN TERIMA KASIH}

Peneliti mengucapkan terima kasih kepada LPPM Universitas HKBP Nommensen Pematangsiantar, dan Dekan FKIP yang telah memfasilitasi kegiatan penelitian ini sehingga terlaksana dengan baik.

\section{DAFTAR PUSTAKA}

Eka Rizki Ananda Nasution, L. (2016). Perbandingan Hasil Belajar Siswa dengan Menggunakan Model Pembelajaran Kooperatif Tipe Make A Match dan Scramble pada Materi Pokok Sistem Ekskresi pada 
4048 Implementasi Model Pembelajaran Kooperatif Make A Match (MAM) dalam Peningkatan Hasil Belajar pada Materi Sistem Ekskresi - Masni Veronika Situmorang, Natalina Purba, Binsar Tison Gultom

DOI: https://doi.org/10.31004/edukatif.v3i6.1286

Manusia di Kelas XI IPA MAN 1 Medan. 4(3), 16-22.

Eliya. (2009). Pengaruh Penerapan Model Pembelajaran Kooperatif Tipe Mencari Pasangan (Make a Match)Terhadap Hasil Belajar Siswa pada Materi P. Universitas Nrgeri Medan.

Eliza Nola Dwi Putri1, T. (2020). Jurnal basicedu. 4(3), 617-623.

Ferdiana, V. (2020). Prosiding Seminar Nasional Sains Pengaruh Model Pembelajaran Kooperatif Tipe Make a Match terhadap Pemahaman Konsep Matematika Siswa. 1(1), 442-446.

H, V. N., \& Halimah, M. (2017). Pengaruh Model Pembelajaran Kooperatif Tipe Make a Match untuk Meningkatkan Hasil Belajar Siswa pada Materi Jenis-jenis Pekerjaan di SD. PEDADIDAKTIKA: Jurnal Ilmiah Pendidikan Guru Sekolah Dasar, 4(2), 199-207.

Haruna, N. H., \& Darwis, M. (2020). Pengaruh Model Pembelajaran Kooperatif Tipe Make a Match Terhadap Hasil Belajar Matematika. Publikasi Pendidikan, 10(3), 223. https://doi.org/10.26858/publikan.v10i3.15159

Lie, A. (2008). Pembelajaran Kooperatif. Rineka Cipta.

Link, Q., Chandra, D., \& Geografi, J. (2019). Vol 8, No 2 (2019). 2254.

Michael, J. A. (2003). Active Learning in Secondary andCollege Science Classrooms A Working Model for Helping the Learner to Learn,. Lawrence Erlbaum Associates, Inc.

Sayuti, I., Syafii, W., Sayuti, I., \& Syafii, W. (2016). The Application of Cooperative Learning Model of Type Student Teams Achievement Division ( STAD ) to Improve the Results of Learning Biology Class VII MTS Nurul Hasanah Stronghold I Sub Pekaitan Year 2015 / 2016 Lessons Penerapan Model Pembelajaran Kooperatif Tipe Student Teams Achievement Division ( STAD ) untuk Nurul Hasanah Kubu I Kecamatan Pekaitan. 20, 1-10.

Slameto. (2010). Belajar dan Faktor -Faktor Yang Mempengaruhinya. Rineka Cipta.

Sudjana. (2010). Metode Statistik. Tarsito.

Syofiana, N., Rohiat, S., \& Hermansyah, A. (2018). Perbandinganhasil Belajar Siswa Menggunakan Model Pembelajaran Kooperatif Tipe Make A Match (MAM) dan Team Games Tournament (TGT) pada Mata Pelajaran Kimia di Kelas X IPA MAN 1 Kota Bengkulu. 2(2), 122-131.

Takdir, A. (2018). Pengaruh Model Pembelajaran Kooperatif Tipe Make A Match terhadap Hasil Belajar Peserta Didik Kelas VII SMP Negeri 4 Kahu ( Materi Pokok Ekosistem ) Sitti Rahma Yunus Sudarto Pendidikan merupakan suatu kebutuhan yang penting bagi setiap manusia . Pendidikan dapat pelatihan dan pengajaran . Tanpa suatu pendidikan seseorang akan sulit untuk menyesuaikan diri warga negara Indonesia berkembang menjadi manusia yang berkualitas sehingga mampu dan proaktif menjawab tantangan zaman yang selalu berubah ( Rusman , 2012:03 ). kemampuan peserta didik yaitu mengembangkan potensi dan kreativitas peserta didik. Selain itu kurikulum yaitu Kurikulum Tingkat Satuan Pendidikan ( KTSP ) menjadi kurikulum 2013 ( K-13 ). 1(2), 68-77.

Winansih, V. (2009). Psikologi Pendidikan. La Tansa Press. 